\title{
Characterization of bioactive molecules isolated from sea cucumber Athyonidium chilensis
}

\author{
Caracterización de moléculas bioactivas aisladas del \\ pepino de mar Athyonidium chilensis
}

\author{
Ignacio Sottorff ${ }^{1,3}$, Ambbar Aballay ${ }^{1,2}$, Víctor Hernández ${ }^{3}$, Luis Roa $^{4}$, \\ Lilian X. Muñoz ${ }^{1}$, Mario Silva ${ }^{3}$, José Becerra ${ }^{3}$ and Allisson Astuya ${ }^{1,2}$
}

${ }^{1}$ Cell Culture and Marine Genomics Laboratory, Marine Biotechnology Unit, Natural and Oceanographic Sciences, Universidad
de Concepción, PO Box 160-C, Concepción, Chile. aastuya@udec.cl
${ }^{2}$ Sur-Austral COPAS Program, Universidad de Concepción, PO Box 160-C, Concepción, Chile
${ }^{3}$ Natural Products Chemistry Laboratory, Botanic Department, Natural and Oceanographic Sciences, Universidad de
Concepción. PO Box 160-C, Concepción, Chile
${ }^{4}$ Agri-Food Laboratories-Concepción, SGS Chile Ltda. Américo Vespucio 820, Parque Industrial Las Arucas, Talcahuano, Chile

Resumen.- En la última década se ha incrementado el interés por la búsqueda de moléculas con potencial biomédico y amigable para el ambiente. Desde esta perspectiva, la búsqueda de principios bioactivos de origen marino ha permitido valorar la diversidad biológica presente en los ecosistemas acuáticos. En el Phylum Equinodermata, se destaca la familia Holothuridae, por su capacidad de sintetizar moléculas como saponinas y otros metabolitos secundarios de alto interés farmacológico debido a su capacidad hemolítica, antitumoral, anti-inflamatoria, antimicrobiana, citostática y antineoplásica. El interés del presente trabajo se centró en la caracterización de un extracto purificado obtenido desde Athyonidium chilensis (Holothuria) mediante técnicas cromatográficas y de espectrometría de masas, con la posterior evaluación de su potencial bioactivo sobre modelos in vitro. Como resultado de estos análisis, se identificaron 2 saponinas. La primera con un peso molecular de 1522 Da y altamente conjugada con monosacáridos. La segunda con un peso molecular de 764 Da fue identificada como holoturinósido D. Respecto a los resultados de la actividad biológica del extracto purificado, éste mostró actividad antibacteriana, antifúngica y citotóxica frente a una línea celular de neuroblastoma. Los resultados de este estudio se convierten en la primera caracterización de moléculas con actividad biológica desde Athyonidium chilensis.

Palabras clave: Holothuria, holoturinósido D, saponina

\begin{abstract}
In the last decade, the interest for searching molecules with biomedical potential as well as innocuous for the environment has been increased. Under this perspective, the search for bioactive principles of marine origin has allowed to value the biological diversity present in aquatic systems. In phylum Echinodermata, the family Holothuridae is distinguished by its capacity of synthesizing molecules such as saponins and other secondary metabolites of high pharmacological interest because of their interesting haemolytic, antitumor, anti-inflammatory, antimicrobial, cytostatic and antineoplastic capacity. The aim of the present study was focused on the characterization of a purified extract obtained from Athyonidium chilensis (Holothuria) by chromatographic and mass spectrometric techniques and the later assessment of its bioactive potential on in vitro models. As a result of these analyses 2 saponins were identified. The first with a molecular weight of $1522 \mathrm{Da}$ and highly conjugated with monosaccharides. The second with a molecular weight of 764 Da was identified as holothurinoside D. The biological activity of the purified extract showed antibacterial, antifungal and cytotoxic activity on a neuroblastoma cell line. Outcomes of this study correspond to the first characterization of molecules with biological activity from Athyonidium chilensis.
\end{abstract}

Key words: Holothuria, holothurinoside D, saponins

\section{INTRODUCTION}

Advances in technology and chemical sciences of natural products have allowed to researchers get focused on sea floor biological diversity, allowing characterizing species and identifying the chemical composition of new molecules with biopharmacological potential (Munro et al. 1999), in order to increase both scientific and commercial value of such species (Ruggieri 1976, Scheuer 1990, Faulkner 2000, Kelly 2005, Bhakuni \& Rawat 2005). 
There are several examples of bioactive products, naturally produced by marine organisms as defense against a highly competitive environment (Bhakuni \& Rawat 2005). Among others, the identification of molecules with anticarcinogenic capacity obtained from the Bryozoa Bugula neritina (Pettit et al. 1996, 2002) can be mentioned, as well as molecules with antitumor and antiviral properties, from the tunicate Trididemnum solidum (Rinehart et al. 1981, Mayer \& Gustafson 2008). Among the molecules with greater pharmacological value found in holothurids, the presence of saponins has been identified; an important bioactive substance originally described only in plants (Li et al. 2006), but later isolated from marine organisms such starfishes and sponges (Regalado et al. 2010, Levina et al. 2010). Their production has been associated to defensive molecules (Kalinin et al. 1996, Van Dyck et al. 2009).

Holothurids are able to synthesize toxins and diverse metabolites from lanosterol (Makarieva et al. 1993). This kind of molecules have pharmacological activity comparable to other species belonging to the same phylum, with antimicrobial and antifungal properties (Neira et al. 1985, Haug et al. 2002, Ismail et al. 2008) and interesting antifouling capacity (Selvin \& Lipton 2004), as well as powerful molecules with anticarcinogenic properties (Bryan et al. 1996, Chludil et al. 2002, Mayer \& Gustafson 2004). Class Holoturoidea belonging to the phylum Echinodermata is represented by 6 orders and 74 species, from which Athyonidium chilensis is the most abundant and widely distributed, from Ancón in Southern Peru and the Southern end of Chile (Larrain 1995). Exploitation of this resource is based exclusively for export, for which 109 tons $\mathrm{yr}^{-1}$ are extracted (SERNAPESCA 2010), destined to Asian countries where it is consumed as a high cost and high nutritional value gastronomic product, having a high source of lipids, polyunsaturated fatty acids and sterols (Drazen et al. 2008). However, there is a lack of studies on potential bioactive compounds found in A. chilensis. For this reason the main objective of this study was focused on the identification of potential bioactive compounds from tissues of $A$. chilensis by means of a number of analytical techniques and the in vitro assessment of their pharmacological potential.

\section{MATERIALS AND METHODS}

\section{Biological material Collection}

Specimens of Athyonidium chilensis (Semper, 1868) were collected from the intertidal zone of the Cocholgüe beach (39³6"S; 7259"W; Fig. 1) during April, 2009. Specimens were maintained in sea water at room temperature and then were transported with constant aeration $\left(100 \mathrm{~L} \mathrm{~h}^{-1}\right)$ to the Cell Culture and Marine Genomics Laboratory at the Universidad de Concepción until processing.

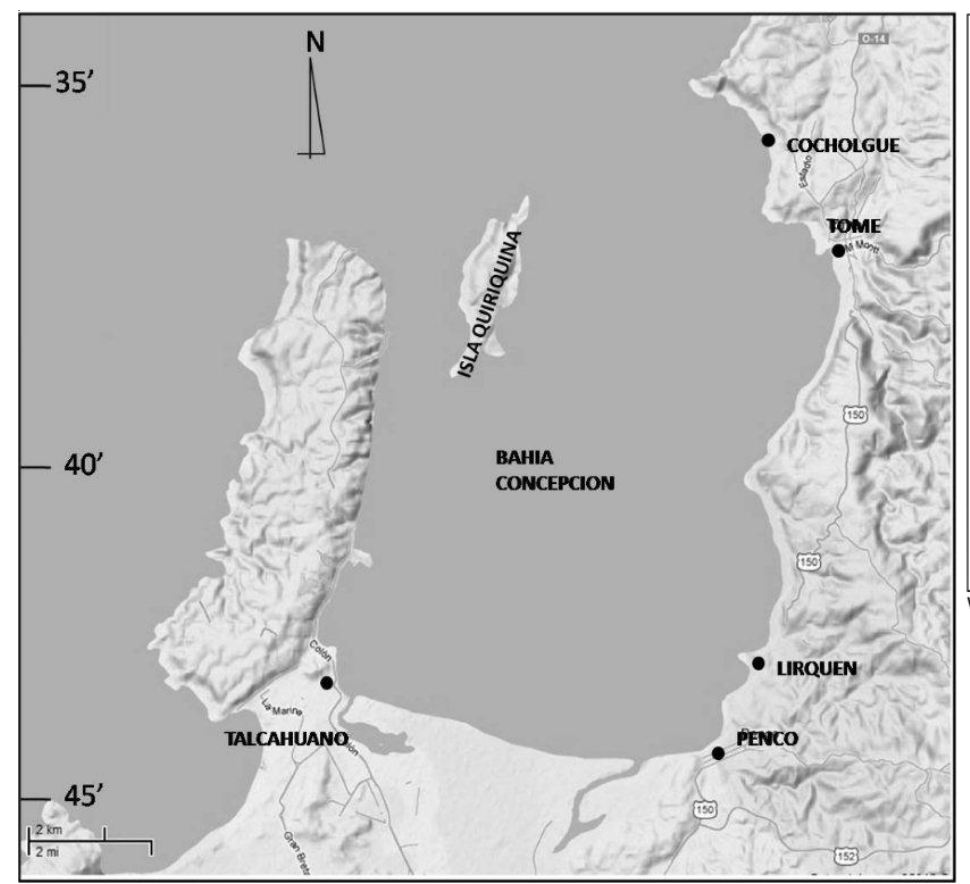

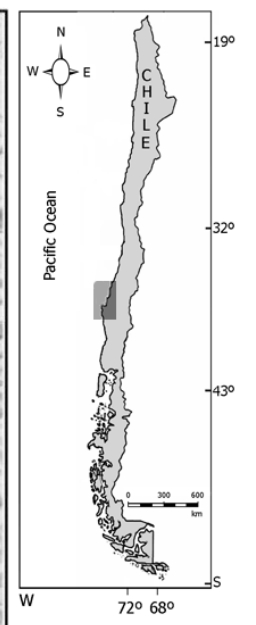

Figure 1. Map of the study area of Cocholgüe beach located near to Concepción, Chile / Mapa del área de estudio de playa Cocholgüe, ubicada en la Provincia de Concepción, Chile 
Preparation of pure extracts of A. chilensis, PREPARATIVE CHROMATOGRAPHY AND ANALYSIS BY LC-MSMS

Specimens were eviscerated, to avoid contamination, and minced to pieces of $1 \mathrm{~cm}^{2}$ or less. From $5 \mathrm{~kg}$ of pooled sample, approximately $1.4 \mathrm{~kg}$ were frozen in glass containers of $500 \mathrm{ml}$ capacity. Samples were then lyophilized in a Lyph Lock 12 Freeze System equipment (Labconco). Once lyophilization was over, dried tissue was transferred to a heater at $40^{\circ} \mathrm{C}$ in order to assure elimination of water. Dehydrated samples were weighted again and the water percentage was calculated. Later, samples containing 10$13 \mathrm{~g}$ were placed in Whatman filter paper cartridges $(11 \mu \mathrm{m}$ pore size). Extraction was carried out following Soxhlet method (Bialy et al. 2004) at $60^{\circ} \mathrm{C}$, and two kinds of solvent were used. First extraction was performed using dichlormethane $\left(\mathrm{CH}_{2} \mathrm{Cl}_{2}\right)$ in order to extract fatty or low polarity compounds (lipophilic) during $3 \mathrm{~d}$ through cycles of $8 \mathrm{~h}$ per day. This process was followed by an extraction in methanol $\left(\mathrm{CH}_{3} \mathrm{OH}\right)$ in order to get the hydrophilic compounds. Extraction in methanol was carried out following the same method indicated above.

Samples were dissolved in $200 \mathrm{ml}$ of distilled water and loaded per $12 \mathrm{~h}$ in an amberlite XAD-7 column (SigmaAldrich) and later washed with distilled water to remove salt from the extract and finally eluted using methanol.

Purification of extracted compounds was carried out by means of column chromatography, using a $3.5 \mathrm{~cm}$ diameter glass column filled with silica gel $60 \mathrm{~F}_{254}$ (Merck). Samples were impregnated with $3 \mathrm{~g}$ silica gel in a porcelain mortar until dryness. Then, samples were carefully mounted in the column, in order to obtain a development of the sample and an optimum separation of the mobile phase constituted by a gradient of chloroform $\left(\mathrm{CHCl}_{3}\right)$ and methanol $\left(\mathrm{CH}_{3} \mathrm{OH}\right)$. Fractions obtained were monitored through fine layer chromatography, using silica gel $60 \mathrm{~F}_{254}$ chromatographic plates, with a mobile phase constituted by $80 \%$ chloroform $\left(\mathrm{CHCl}_{3}\right), 19 \%$ methanol $\left(\mathrm{CH}_{3} \mathrm{OH}\right)$ and $1 \%$ water $\left(\mathrm{H}_{2} \mathrm{O}\right)$. At the same time, in some cases reverse phase chromatographic phases (RP-18) were used.

\section{CHROMATOGRAPHIC IDENTIFICATION AND DETERMINATION OF MOLECULAR WEIGHT}

LC-MS-MS analysis was carried out in a MDS SCIEX liquid chromatographer (Applied Biosystems), equipped with an Agilent 1200 series quaternary pump, Agilent 1200 vacuum degasser, Agilent Hip-Als, automatic sampler with temperature control, Agilent 1200 column thermostatizer, and 3200 Q trap LC-MS-MS System detector. Fractions were injected in the equipment loop, in a volume of $15 \mu \mathrm{l}$ per sample. As mobile phase a $\mathrm{CH}_{3} \mathrm{CN}: \mathrm{H}_{2} \mathrm{O}$ gradient (HPLC quality) in $\mathrm{C}_{18}$ column (Sunfire Waters Company) was used with a $2.5 \mu \mathrm{m}$ particle size and $21 \mathrm{~cm}$ length. In order to improve chromatographic peaks, $1 \%$ formic acid was added in the mobile phase. Determination of molecular weight of the fraction 18 was carried out by means of an Applied Biosystems Q trap 3200 mass spectrometer. This was injected with different solvents in order to obtain a comparison of the molecular weights in the different injections. The first one was added to a $\mathrm{CH}_{3} \mathrm{OH}: \mathrm{H}_{2} \mathrm{O}$ (50:50\%) mixture; the second one, in $\mathrm{CH}_{3} \mathrm{OH}: \mathrm{H}_{2} \mathrm{O}$ : formic acetate mixture and the third one was performed in a mixture of $\mathrm{CH}_{3} \mathrm{OH}: \mathrm{H}_{2} \mathrm{O}$ and $1 \%$ formic acid. A direct infusion to the spectrometer was performed at 20 $\mu \mathrm{l} \mathrm{min}{ }^{-1}$ of the methanolic fraction in order to obtain first order spectra of the fraction (elution having analytes if interest) previously evaporated under nitrogen current at $40^{\circ} \mathrm{C}$. The extract was dissolved in a 1:1 methanol: water mixture, with addition of $5 \mathrm{nM}$ ammonium acetate and filtered through a $0.22 \mu \mathrm{m}$ PTFE membrane. Ionization was carried out by means of the electrospray mode (ESI) both positive and negative, with parameters of the ion source of 70, -70 for DP, 10, -10 for EP and 20, -20 for CEP. Capillary voltage was 400 and -4500 Volt in positive and negative mode, respectively. A scanning between 700 and 1700 uma was performed for both ionization modes at $50^{\circ} \mathrm{C}$; with a GS1 and GS2 curtain gas of 40 and 50 arbitrary units respectively. Q1 Quadrapole resolution was of 0.4 uma. In the case of the chromatographic analysis $10 \mu \mathrm{L}$ of the extract were injected in a TSK-gel column of $2.1 \times 150$ $\mathrm{mm}$, with $3.5 \mu \mathrm{m}$ particle size. Used flow was $0.25 \mu \mathrm{min}^{-1}$ and oven temperature of $45^{\circ} \mathrm{C}$. Elution was performed in gradient. With $100 \%$ aqueous phase in the beginning, and later linearly increased the organic phase B at 95\% at $25 \mathrm{~min}$ and kept for other $5 \mathrm{~min}$ in order to remove impurities of the column and return to the initial condition at 35 min for a new injection.

\section{Bioprospecting OF BIOLOGICAL ACTIVITY}

\section{Hemolytic TEST}

To determine the presence of saponins in the primary extracts of dichloromethane and methanol, the hemolytic test was used following a method described by Gestetner et al. (1968). Saturated discs with the extracts were placed on blood agar plates for $24 \mathrm{~h}$. Hemolytic halos formed around the discs were proportional to the hemolytic 
potential or saponin concentration. Also, this test was performed with the fractions purified from the methanolic extract.

\section{Antibacterial test}

The evaluation of the antibacterial activity was performed against Gram-positive bacteria: Staphylococcus aureus (ATCC 25923) and Bacillus subtilis (ATCC 6633), and against Gram-negative bacteria: Escherichia coli (ATCC 25922), Salmonella sp. and Pseudomonas sp., obtained from the bacterial collection of the Environmental Microbiology Laboratory at the Faculty of Biological Sciences of the Universidad de Concepción. Bacteria were incubated at a concentration of $10^{6} \mathrm{UFC} \mathrm{ml}^{-1}$ for $24 \mathrm{~h}$ at $37^{\circ} \mathrm{C}$ in Trypticase soy agar at $37^{\circ} \mathrm{C}$ on $10 \mathrm{~cm}$ Petri dishes. Extract of A. chilensis was used at $10 \mathrm{mg} \mathrm{ml}^{-1}$, and a mix of penicillin and streptomycin (10000 IU and $10 \mathrm{mg} \mathrm{ml}^{-1}$, respectively) was used as a reference antibiotic. The diameter of the halo of bacteria growth inhibition, or zone of inhibition, was measured after $24 \mathrm{~h}$ of incubation with the extract.

\section{Antifungal Test}

In order to assess antifungal properties Aspergillus sp., Botrytis sp., Rhizopus sp. and C. albicans coming from the fungal culture collection of the Natural Products Chemistry Laboratory (Universidad de Concepción) were used. Spores of Aspergillus sp., Botrytis sp. and Rhizopus sp. were placed in a $\mathrm{H}_{2} \mathrm{O}$ :Tween $20(10: 1)$ solution and quantified using a hemocytometer. Standard concentration used was $1 \times 10^{6}$ spores per $10 \mathrm{~cm}$ Petri dish in HA agar. Purified extract was place in wells of $100 \mu \mathrm{l}$ at a concentration of $10 \mathrm{mg} \mathrm{ml}^{-1}$ and incubated at $20^{\circ} \mathrm{C}$. Finally, the zone of inhibition generated around the extract samples was measured at $72 \mathrm{~h}$. C. albicans was tested with the same conditions used for bacteria (incubation in Trypticase soy agar for $24 \mathrm{~h}$ ). As positive control $10 \mathrm{mg} \mathrm{ml}^{-1}$ Ketoconazole was used.

\section{CYTOTOXICITY TEST ON MAMMAL CELLS}

Neuro 2a (ATCC CCL-131) mouse neuroblastoma cell line was allowed to grow in RPMI 1640 (Invitrogen) culture media, supplemented with $10 \%$ fetal bovine serum (FBS, Invitrogen), $0.25 \mu \mathrm{g} \mathrm{ml}^{-1}$ amphoteromicin B (Invitrogen), $100 \mathrm{IU} \mathrm{ml}^{-1} 100 \mu \mathrm{g} \mathrm{ml}^{-1}$ penicillin - streptomycin (Invitrogen), $1 \mathrm{mM}$ sodium piruvate (Invitrogen) and 2 $\mathrm{mM}$ glutamine (Invitrogen). Cells were maintained at $37^{\circ} \mathrm{C}$ in an incubator (Thermo Scientifics), with injection of 5\%
$\mathrm{CO}_{2}$. In order to determine the cytotoxicity of A. chilensis extracts on the tumor cell line of mouse neuroblastoma N2a, the inhibition of cell growth was evaluated at $24 \mathrm{~h}$ post-exposure, by means of the MTT (3-(4,5dimethylthiazol-2-yl)-2,5-diphenyltetrazolium bromide) (Invitrogen) colorimetric assay, according to the method described by Manger et al. (1993) for determination of cell viability. A density of $15 \times 10^{4}$ cells ml ${ }^{-1}$ in $200 \mu \mathrm{L}$ of culture medium supplemented with 5\% FBS was grown in 96 wells-plates (Nunc) at $37^{\circ} \mathrm{C}$ and $5 \% \mathrm{CO}_{2}$ for $24 \mathrm{~h}$. Later, $30 \mu \mathrm{l}$ of different concentrations of A. chilensis extract (from $3.9 \mu \mathrm{g} \mathrm{ml}^{-1}$ to $1500 \mu \mathrm{g} \mathrm{ml}^{-1}$ ) were added. Also, control without extract was tested. Absorbance was quantified at $570 \mathrm{~nm}$, in a Biotek EL-800 plate reader. The cell viability of N2a cells was expressed as a percentage of the control without extract. Every value was indicated as the average \pm SD ( $n=8)$ with 2 experimental replicates.

\section{Results}

The first methanolic extract of A. chilensis showed hemolytic activity (data not shown). Therefore, this extract was under further purification. This purification was carried out by means of column chromatography, using chloroform, methanol and water. This method allowed the separation of the extract in 19 different fractions, from which only 3 exhibit hemolytic activity, but fraction 18 showed the greatest bioactivity on a specific test for saponins (blood agar test). Its yield reached only $0.03 \%$ related to the dry weight of the sample.

The characterization of the polar compounds from the methanolic fraction of the extraction of $A$. chilensis by means of HPLC showed the presence of 3 compounds, with retention times (RT) of 1.20, 3.25 and $6.06 \mathrm{~min}$, and molecular weights of 508.5, 1015.8 and $1544 \mathrm{Da}$, respectively (Fig. 2).

By means of LC-MS-MS, molecules contained in fraction 18 were characterized. The first order mass spectrum in positive mode (Fig. 3A) presents 5 clusters with species of the form $[\mathrm{M}+\mathrm{H}]^{+}$, with masses of 507 (M1), 765 (M2), 1015 (M3), 1272 (M4) and 1523 (M5) Da. Species forming adducts with sodium are also observed, generating mass differences of 23 Da for every one of them.

In negative electrospray mode (Fig. 3B) the presence of 5 clusters can also be observed with masses of 566 (M1), 823 (M2), 1073.8 (M3), 1330 (M4) and 1581 (M5) Da. Every one of these species corresponds to a number of adducts with acetate ion (A) present in the ionization 


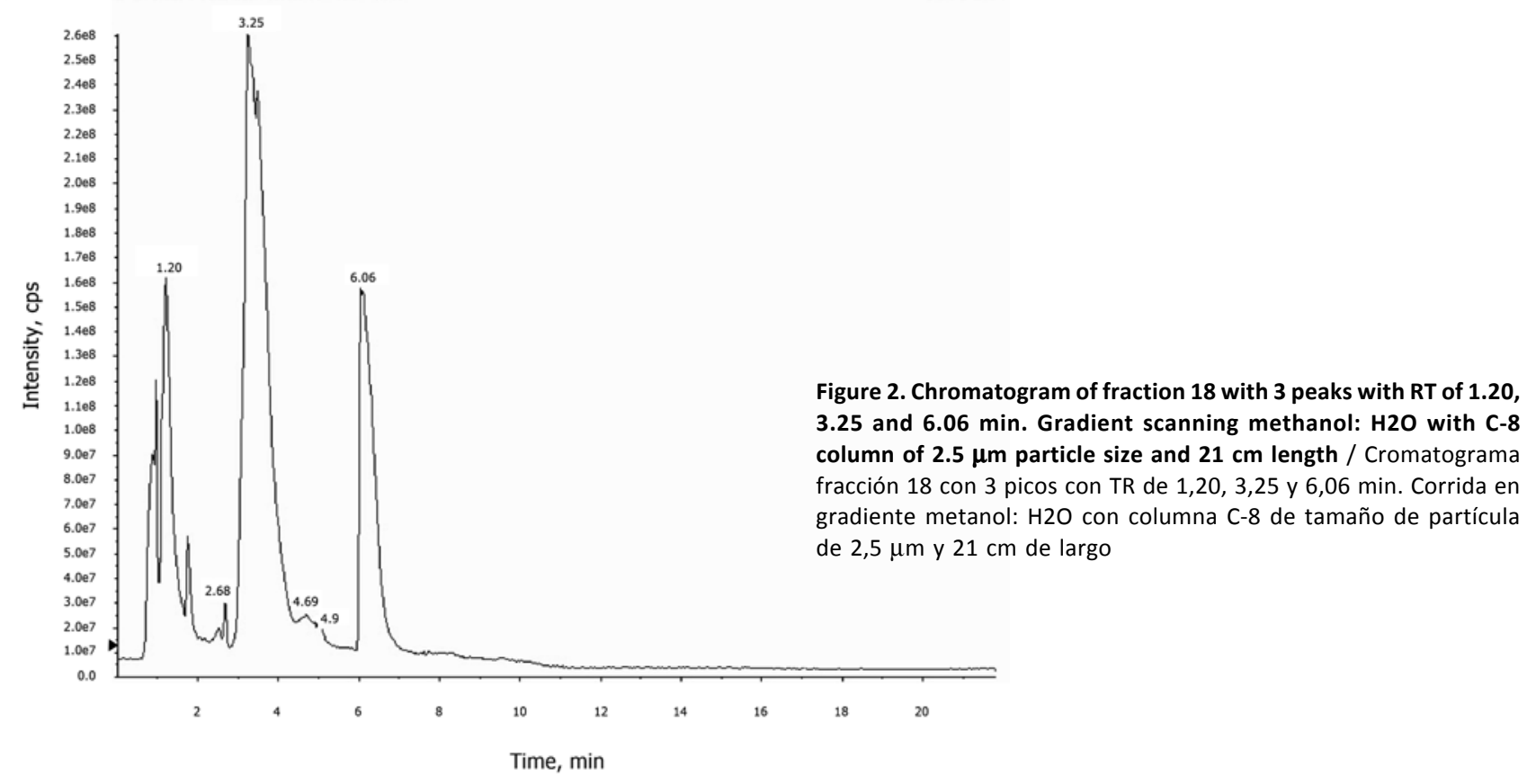

Table 1. Species and molecular masses asigned for fraction 18. Ionization was carried out by means of the electrospray mode (ESI) both positive and negative / Especies y masas moleculares asignadas para la fracción 18. La ionización fue llevada a cabo en modo electrospray (ESI) positivo y negativo

\begin{tabular}{|c|c|c|c|c|c|}
\hline Compound & $\mathrm{ESI}+$ & $\mathrm{m} / \mathrm{z}(\mathrm{amu})$ & ESI - & $\mathrm{m} / \mathrm{z}(\mathrm{amu})$ & Molecular weight (amua) \\
\hline \multirow[t]{3}{*}{ M1 } & {$[\mathrm{M} 1+\mathrm{H}]^{+}$} & 507 & {$[\mathrm{M} 1+\mathrm{A}]^{-}$} & 566 & 506 \\
\hline & {$[\mathrm{M} 1+\mathrm{Na}]^{+}$} & 530 & & & \\
\hline & {$[\mathrm{M} 1+\mathrm{K}]^{+}$} & 546 & & & \\
\hline \multirow[t]{3}{*}{ M2 } & {$[\mathrm{M} 2+\mathrm{H}]^{+}$} & 765 & {$[\mathrm{M} 2+\mathrm{A}]^{-}$} & 823 & 764 \\
\hline & {$[\mathrm{M} 2+\mathrm{Na}]^{+}$} & 787 & & & Holothurinoside D \\
\hline & {$[\mathrm{M} 2+\mathrm{K}]^{+}$} & 803 & & & \\
\hline \multirow[t]{3}{*}{ M3 } & {$[\mathrm{M} 3+\mathrm{H}]^{+}$} & 1015 & {$[\mathrm{M} 3-\mathrm{A}]^{-}$} & 1073,8 & 1014 \\
\hline & {$[\mathrm{M} 3+\mathrm{Na}]^{+}$} & 1037 & & & \\
\hline & {$[\mathrm{M} 3+\mathrm{K}]^{+}$} & 1053 & & & \\
\hline \multirow[t]{3}{*}{ M4 } & {$[\mathrm{M} 4+\mathrm{H}]^{+}$} & 1272 & {$[\mathrm{M} 4+\mathrm{A}]^{-}$} & 1330,8 & 1271 \\
\hline & {$[\mathrm{M} 4+\mathrm{Na}]^{+}$} & 1294 & & & \\
\hline & {$[\mathrm{M} 4+\mathrm{K}]^{+}$} & NF & & & \\
\hline \multirow[t]{3}{*}{ M5 } & {$[\mathrm{M} 4+\mathrm{H}]^{+}$} & 1523 & {$[\mathrm{M} 5+\mathrm{A}]^{-}$} & 1581 & 1522 \\
\hline & {$[\mathrm{M} 5+\mathrm{Na}]^{+}$} & 1545 & & & \\
\hline & {$[\mathrm{M} 5+\mathrm{K}]^{+}$} & 1561 & & & \\
\hline
\end{tabular}

ESI: Electrospray Ionization. $\mathrm{m} / \mathrm{z}$ : mass to charge ratio. amu: atomic mass unit. A: acetate. NF: not found

vehicle. Masses distribution is correlated with the spectrum in a positive way, where molecular weight is possible to be assigned (Table 1).

The results from the evaluation of microbiological activity for the chromatographically purified fraction 18 from A. chilensis against 5 clinically important microorganisms showed antimicrobial activity against Gram-positive bacteria such as $S$. aureus and B. subtilis, with a zone of inhibition of $22 \pm 2$ and $19 \pm 1 \mathrm{~mm}$, respectively. On the other side, there was no evidence of activity against the Gram-negative bacteria analyzed (Fig. 4). 
A

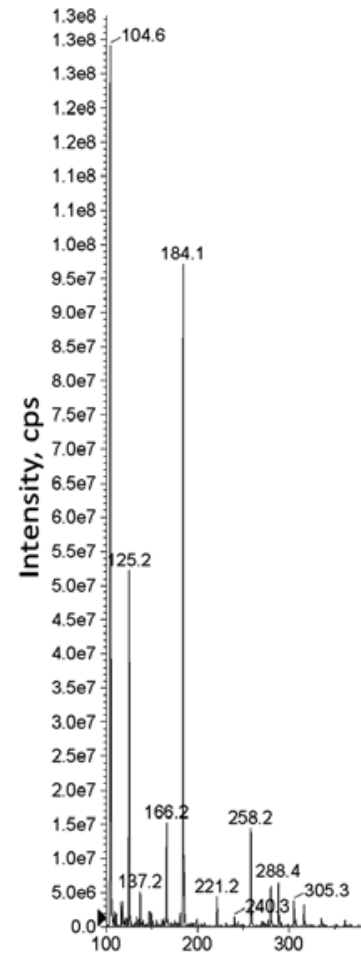

1015

507

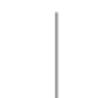

0.4

765

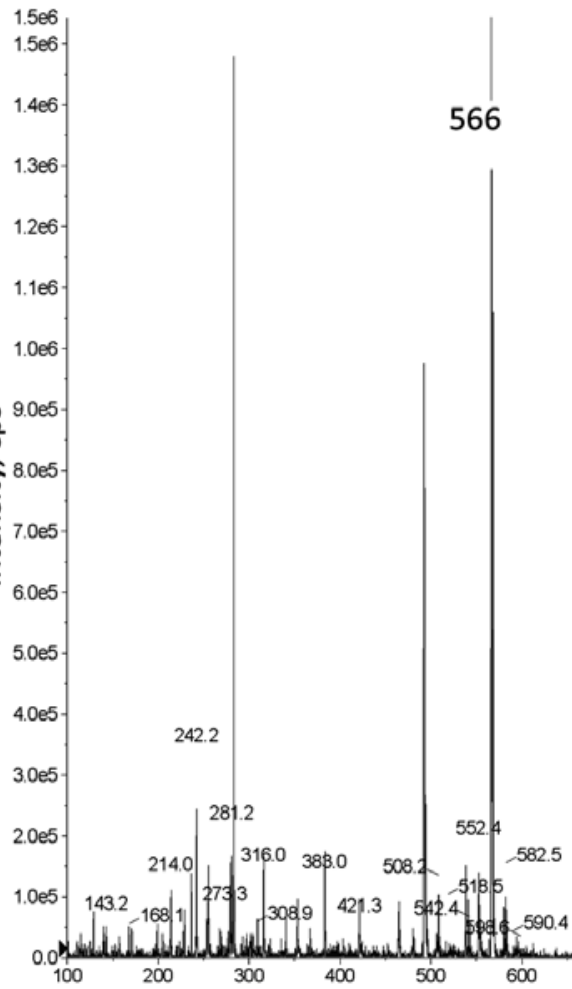

Figure 3. First order mass spectrum for fraction 18. A) Analysis in positive electrospray mode. B) Analysis in negative electrospray mode / Espectro de masas de primer orden de Fracción 18. A) Representa análisis en modo electrospray positivo B) Análisis en modo electrospray negativo

Max. $1.5 \mathrm{e} 6 \mathrm{cps}$.

\section{B}


Antifungal activity of the extract was evaluated on 4 microorganisms medically and commercially important (Zahavi et al. 2000, Pasqualotto \& Denning 2008). Fraction 18 showed activity against Aspergillus sp., Botrytis sp. and $C$. albicans, with a zone of inhibition of $24.5 \pm 4,13.5$ \pm 3 and $22 \pm 1 \mathrm{~mm}$, respectively. There was no activity against Rhizopus sp. (Fig. 5).
Finally, the extract from A. chilensis characterized by the presence of saponins (fraction 18) showed citotoxic activity on the tumor cell line N2A. A dose-depending reduction in the cell viability was detected with an $\mathrm{IC}_{50}$ of $77.34 \pm 1.6 \mu \mathrm{g} \mathrm{ml}^{-1}$ (Fig. 6).
Figure 4. Representation of the antibacterial activity between fraction $18\left(10 \mathrm{mg} \mathrm{ml}^{-1}\right.$, white bars) and reference antibiotic (PenicillinStreptomycin $10 \mathrm{mg} \mathrm{ml}^{-1}$, black bars) / Representación de la actividad antibacteriana entre la fracción 18 (10 $\mathrm{mg} \mathrm{ml}^{-1}$, barras blancas) y el antibiótico de referencia (PenicilinaEstreptomicina $10 \mathrm{mg} \mathrm{ml}^{-1}$, barras negras)

Figure 5. Representation of the antifungal activity between fraction $18\left(10 \mathrm{mg} \mathrm{ml}^{-1}\right.$, white bars) and referenced antifungal (10 $\mathrm{mg} \mathrm{ml}^{-1}$, black bars) / Representación de la actividad antifúngica, entre la fracción $18\left(10 \mathrm{mg} \mathrm{ml}^{-1}\right.$, barras blancas) y el antifúngico de referencia (10 $\mathrm{mg} \mathrm{ml}^{-1}$, barras negras)
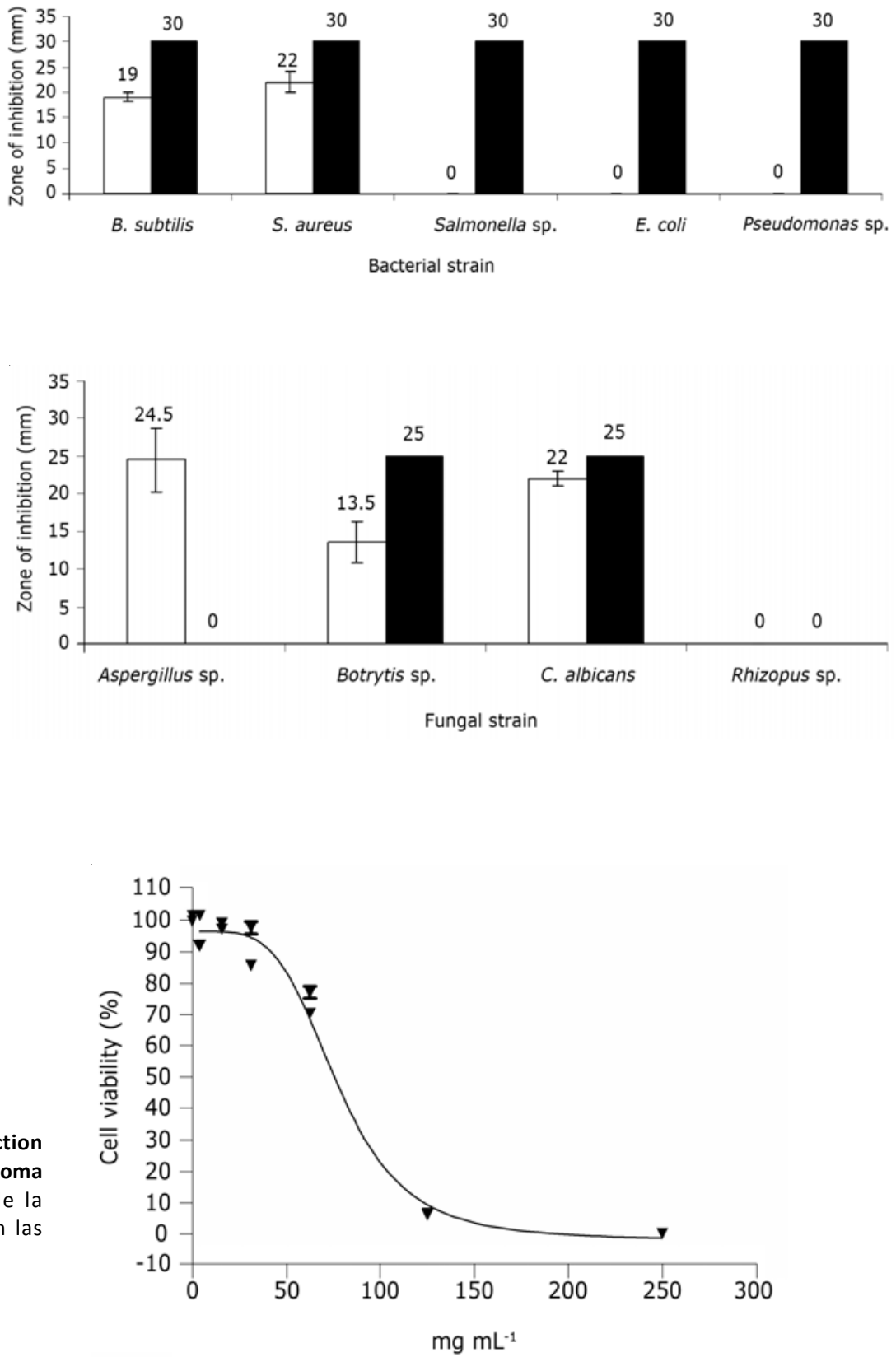

Figure 6. Dose-response curve of the fraction 18 on the cell viability of mouse neuroblastoma N2a cells / Curva de dosis-respuesta de la fracción 18 sobre la viabilidad celular en las células N2a de neuroblastoma de ratón 


\section{Discussion}

A considerable number of reports have demonstrated the presence of bioactive metabolites in holothurids, with an important diversity of glycosylated triterpenes, called saponins (Kobayashi et al. 1991, Stonik et al. 1999, Chludil et al. 2003, Kalinin et al. 2005, Antonov et al. 2011). These saponins are described for sea cucumber species collected in tropical zones of the Pacific and Indian Oceans (Stonik et al. 1999), Mediterranean Sea (Silchenko et al. 2005), North Atlantic (Silchenko et al. 2007), North Pacific (Silchenko et al. 2008) and some sea cucumber from the Antarctic Sea (Maier et al. 2001, Antonov et al. 2008, 2009). However, there is a lack of reports about secondary metabolites and saponins of sea cucumber from South American coasts.

The election of solvents and the methodological extraction strategy of active metabolites from marine organisms are fundamental steps for the following evaluation of biological activity, because it allows concentrate, separate and clean the potential bioactive molecules from the biological matrix of the marine organisms. Specifically, in marine organisms it has been suggested the use of alcoholic extractions based on ethanol or methanol. However, this kind of extraction is useful for the preparation of total extracts, which are more complex extracts, with low yields of the total sample weight, and makes difficult to identify the bioactive principles as unique compounds (Silchenko et al. 2008, Avilov et al. 2008). Therefore, the strategy used in this work included differentiated extraction with solvents of increasing polarity. This methodology can be divided in 2 steps: a first non-polar extraction with dichloromethane, in which similar compounds as lipids and non-polar metabolites are extracted; and a second hydrophilic extraction using methanol as solvent in order to obtain more polar compounds. This approximation allowed the enrichment of the extracts into highly hydroxylated metabolites, which would correspond to the phenolic compounds described by Mamelona et al. (2007), who described greater yields in the presence of aqueous solvents, especially from muscle and gonads in sea cucumbers from the Atlantic Sea.

\section{IDENTIFICATION OF SAPONINS}

Currently, the utilization of LC-MS-MS is emphasized by using triple quadrupole mass spectrometry with turbulonspray ionization interface in order to obtain molecular ions and the molecule fragmentation (Van Dyck et al. 2009). Thus, being know molecular weight and atoms distribution, a chemical characterization of them can be built.

The major problem in characterizing glycosides is the capacity of forming adducts with other molecules. This induces the integration of molecules of the analyte with other molecules from the mobile phase, originating clusters with certain deviation, which are presented as $[\mathrm{M}+\mathrm{H}]$. Isotopic distribution of the molecules can be observed around every cluster, as well as the formation of adducts with $\mathrm{H}^{+}$or $\mathrm{Na}^{+}$. This kind of adduct has been reported by several authors for saponin analyses (Van Dyck et al. 2009). In the spectrum of the first order masses, on positive mode, the presence of 5 clusters can be observed. In every one of them, molecular species that correspond to adducts with protons and cations coming from the ionization additive used can be noticed. The most abundant species are those with protons and sodium. Such profile is analogous to that one obtained from Holothuria forskali (Van Dyck et al. 2009). The first species, denominated M1, of 507 Da, could correspond to 2 different structures and both correspond to a chain of monosaccharides and the aglucon, conjugated with a proton. When it is associated to a sodium atom, its mass increases to $530 \mathrm{Da}$. Similar behaviours can be observed for the 4 remaining species, being those species of masses 765, 1015, 1272 y $1523 \mathrm{Da}$, of the form $[\mathrm{M}+\mathrm{H}]^{+}$for M2, M3, M4 and M5 (Table 1). Also, molecular species composed by sodium with mass differences of 23 Da for every one of them can be observed (Table 1).

In negative electrospray mode, 5 ion clusters, with lower number of adducts and intensity can be observed. This behaviour is characteristic in this kind of ionization. In this spectrum, the presence of 5 clusters can be observed: 566 (M1), 823 (M2), 1073.8 (M3), 1330 (M4) and 1581 (M5) Da. Every one of them corresponds to adducts with ion acetate (A) present in the ionization vehicle. Such mass distribution is correlated to the spectrum in positive mode, being possible to assign the molecular weight to the fragments or molecules after the ionization present in fraction 18. Thus, a molecular weight of 764 Da was assigned to the M2 molecule. Then, species of the form $[\mathrm{M} 2+\mathrm{H}]^{+}$and $[\mathrm{M} 2+\mathrm{Na}]^{+}$of 765 and $787 \mathrm{Da}$ are confirmed in positive mode with differences of 1 and $23 \mathrm{Da}$, respectively. In negative mode, the species $[\mathrm{M} 2+\mathrm{A}]$ - of 823 Da with a difference of $60 \mathrm{Da}$ is observed. Molecular weights of the other saponins were equally assigned. From the species identified in Table 1 , the one with a mass of $787 \mathrm{Da}$ corresponds to the saponin 
holothurinoside D (Fig. 7), isolated from Holothuria forskali by Rodriguez et al. (1991). The remaining chemical species described would correspond to new saponins isolated from Athyonidium chilensis. However, the high complexity of the saponins mixtures from these extracts makes difficult their structural elution and the evaluation of their potential biological role.

The evaluation of the biological activity of purified extracts isolated from A. chilensis showed a remarkable activity against Gram positive bacteria such as $S$. aureus and $B$. subtilis, but not against Gram negative bacteria tested in this study. These results are in agreement with observations described by Haug et al. (2002), who determined that most of the extracts prepared from different organs of the holothurid Cucumaria frondosa showed antibacterial activity against Gram positive and no activity against Gram negative such as E. coli and
Vibrio sp., also suggesting that the antimicrobial activity would not be exclusively attributed to the presence of enzymes such as lisozime or other antimicrobial peptides (Haug et al. 2002), but it would be related to the presence of secondary metabolites like saponin in the extracts from A. chilensis.

According to the evaluation of the antifungal activity, though they suggest the presence of antagonistic molecules on proliferation of fungi such as Aspergillus sp. and Botrytis sp. did not show activity against Rhizopus sp. This would be explained exclusively on the basis of the specific inhibition mechanisms, which were not considered in this study. However, these results are congruent with what has been reported for holothurid species C. frondosa and C. japonica (Attaway \& Zaborsky 1993).

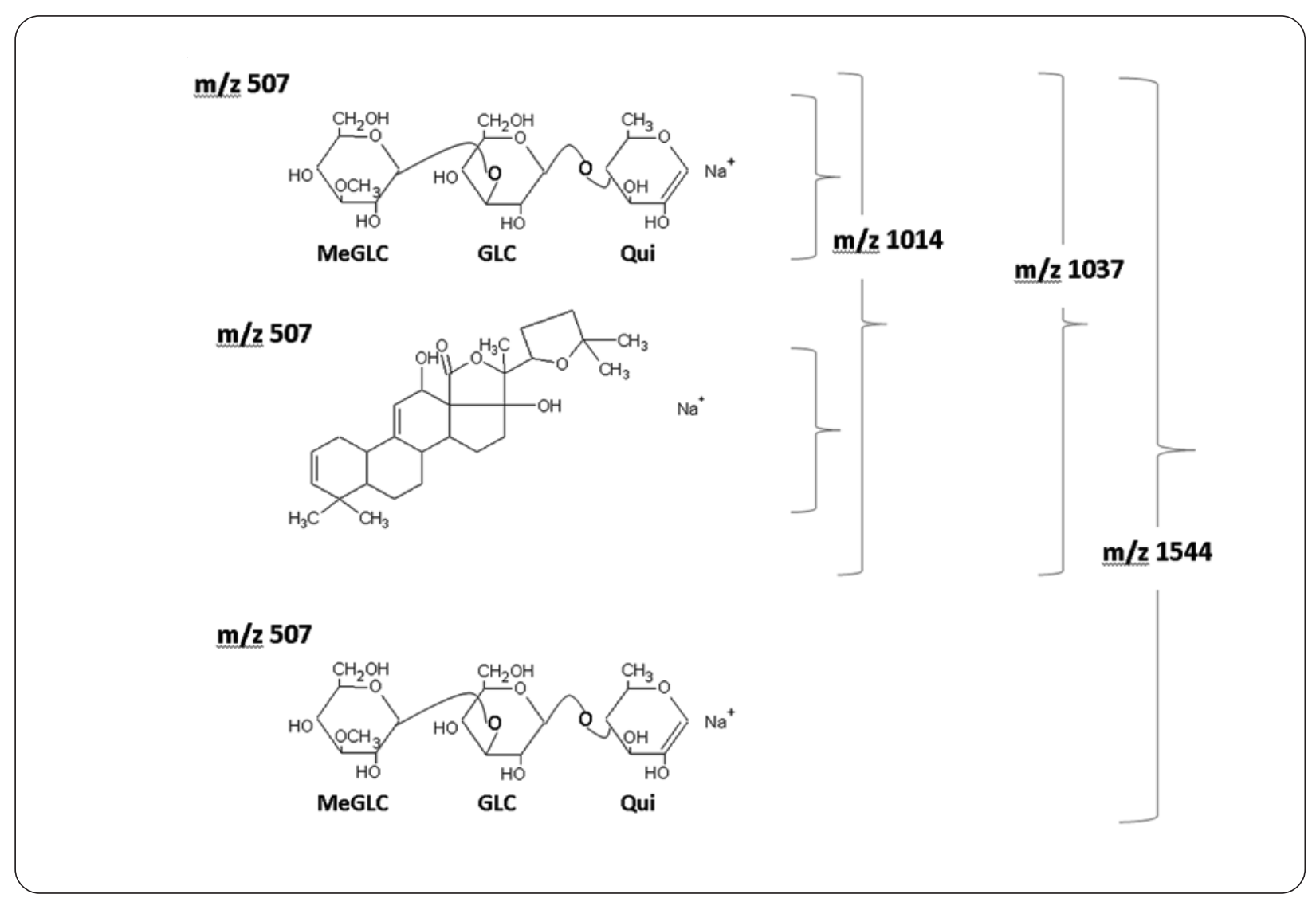

Figure 7. Presumptive molecular structure of a derivative holothurinoside $\mathrm{D}$ isolated from Athyonidium chilensis / Presumible estructura molecular de un derivado de holoturinósido D aislado desde la especie Athyonidium chilensis 
There are reports about the antiproliferative potential of sphingolipids and branched chain fatty acids obtained from extracts of sea cucumbers on cell lines of peripheral tumours such as prostate cancer cells (Yang et al. 2003) and colon cancer cells (Sugawara et al. 2006). However, there are no records of its evaluation on cell lines from neuroblastoma. Our results showed that the extract purified of saponins is capable to reduce both proliferation and cell viability of the N2a tumour cell line after $24 \mathrm{~h}$, with an $\mathrm{IC}_{50}$ of $77.3 \pm 1.6 \mu \mathrm{g} \mathrm{ml}^{-1}$ (Fig. 6). These results of cytotoxicity on N2a cells are correlated with the antiproliferative properties described for total or enriched extracts isolated from other species of sea cucumbers in cell lines of human tumours of peripheral origin such as A549, MCF-7, 1A9, CAKI-1, U-87-MG, PC3, KB, KB-VIN, SK-MEL-2, HCT-8 (Zou et al. 2006, Sugawara et al. 2006). Antiproliferative activity has been attributed to the purification or enrichment of certain molecules like saponins and triterpenic glycosides for which different mechanisms are suggested. Among these mechanisms, selective inhibition by arrest of the cell cycle (Mujoo et al. 2001), specific cytotoxic activity influenced by the glycosylated portion of the saponin structure (Kuroda et al. 2001), and non-specific cytotoxicity caused by detergent action (Mimaki et al. 2001) can be mentioned. Additionally, there are previous information on the basis that sphingolipids isolated from sea cucumber are able to induce apoptosis on colon cancer cells (Sugawara et al. 2006). On the other side, other molecules such as leptosines are able to produce inhibition of the in vitro proliferation on tumour cell lines by means of the specific inhibition of the protein kinase and topoisomerase II (Jha \& Zi-rong 2004).

In conclusion, this study demonstrated that the fraction 18 obtained from A. chilensis contains 2 saponins, which are identified through LC-MS-MS. The first saponin has a molecular weight of $1522 \mathrm{Da}$, whis is fragmented in diverse small molecules, such as monosaccharides or the aglucon (Fig. 7). The other saponin that could be identified was of 764 Da and would correspond to the saponin named holothurinoside D, previously identified in Holothuria forskali by Rodriguez et al. (1991). The other chemical species described in this study would correspond to new saponins identified from A. chilensis. Additionally, saponin purified extracts showed an interesting hemolytic, antibacterial and antifungal activity. However, the efficiency of the last 2 activities is lower respect to what was observed for other members of the family Holothuridae. On the other side, in relation to the evaluation of the in vitro antiproliferative properties of the extracts obtained from A. chilensis, it can be concluded that it is presented as an interesting focus of study as potential cytotoxic biomedicines of marine origin for the treatment of cancer. An example of this is Frondoside A, isolated from sea cucumber which demonstrated an important antimetastatic activity (Ma et al. 2012).

Altogether, our results have become into the first characterization of molecules with biological activity from Anthyonidium chilensis which, in the long term, would give an added value to this resource and it can be propose it as a potential source of biomedicines. Even though its poor yield does complex its commercial exploitation, it is a good source of new molecules which can be produced at a bigger scale.

\section{ACKNowledgements}

This research was supported by COPAS Sur-Austral Program Conicyt (Project PFB-31/2007), Ring project ACT38 (CONICYT) and the project DIUC 208.112.100-1. Universidad de Concepción, Chile. We are thankful to Dr. María Angélica Mondaca of the Department of Microbiology at the Universidad de Concepción for her valuable helping in microbiological analysis. We would like to make a special mention and a great recognition to Marcela Silva y Zenón Rozas for their collaboration in this work.

\section{LITERATURE CITED}

Antonov AS, SA Avilov, AI Kalinovsky, SD Anastyuk, PS Dmitrenok, E Evtushenko, VI Kalinin, AV Smirnov, S Taboada, M Ballesteros, C Avila \& VA Stonik. 2008. Triterpene glycosides from Antarctic sea cucumbers I. Structure of liouvillosides A1, A2, A3, B1 and B2 from the sea cucumber Staurocucumis liouvillei: new procedure for separation of highly polar glycoside fractions and taxonomic revision. Journal of Natural Products 71: 1677-1685.

Antonov AS, SA Avilov, AI Kalinovsky, SD Anastyuk, PS Dmitrenok, VI Kalinin, S Taboada, A Bosh, C Avila \& VA Stonik. 2009. Triterpene glycosides from Antarctic sea cucumbers 2. Structure of achlioniceosides A1, A2 and A3 from the sea cucumber Achlionice violaescupidata (=Rhipidothuria racowitzai). Journal of Natural Products 72: 33-38.

Antonov AS, SA Avilov, AI Kalinovsky, PS Dmitrenok, VI Kalinin, S Taboada, M Ballesteros \& C Avila. 2011. Triterpene glycosides from Antarctic sea cucumbers III. Structures of liouvillosides A4 and A5, two minor disulphated tetraosides containing 3-O-methylquinovose 
as terminal monosaccharide units from the sea cucumber Staurocucumis liouvillei (Vaney). Natural Product Research 25: 1324-1333.

Attaway DH. \& OR Zaborsky. 1993. Marine biotechnology In: Attaway DA \& OR Zaborsky (eds). Pharmaceutical and bioactive natural products 1: 1-524. Plenum Press, New York.

Avilov SA, AS Silchenko, AS Antonov, VI Kalinin, AI Kalinovsky, AV Smirnov, PS Dmitrenok, EV Evtushenko, SN Fedorov, AS Savina, LK Shubina \& VA Stonik. 2008. Synaptosides A and A1, triterpene glycosides from the sea cucumber Synapta maculata containing 3-O-methylglucuronic acid and their cytotoxic activity against tumor cells. Journal of Natural Products 71: 525-531.

Bhakuni DS \& DS Rawat. 2005. Bioactive marine toxins. In: Bhakuni DS \& DS Rawat (eds). Bioactive marine natural products, pp. 151-207. Springer, New Delhi.

Bialy Z, M Jurzysta, M Mella \& A Tava. 2004. Triterpene saponins from aerial parts of Medicago arabica L. Journal of Agricultural and Food Chemistry 52: 1095-1099.

Bryan PJ, D Rittschof \& JB McClintock. 1996. Bioactivity of echinoderm ethanolic body-wall extracts: an assessment of marine bacterial attachment and macroinvertebrate larval settlement. Journal of Experimental Marine Biology and Ecology 196: 79-96.

Chludil HD, CC Muniain, AM Seldes \& MS Maier. 2002. Cytotoxic and antifungal triterpene glycosides from the Patagonian sea cucumber Hemoiedema spectabilis. Journal of Natural Products 65: 860-865.

Chludil HD, AP Murray, AM Seldes \& MS Maier. 2003. Biologically active triterpene glycosides from sea cucumbers (Holothurioidea, Echinodermata). In: Rahman A (ed). Studies in natural products chemistry 28: 587-616. Elsevier Science, Amsterdam.

Drazen JC, CF Phleger, MA Guest \& PD Nichols. 2008. Lipid, sterols and fatty acid composition of abyssal holothurians and ophiuroids from the North-East Pacific Ocean: Food web implications. Comparative Biochemistry and Physiology Part B: Biochemistry and Molecular Biology 151: 79-87.

Faulkner DJ. 2000. Marine pharmacology. Antonie Van Leeuwenhoek 77: 135-145.

Gestetner B, Y Birk \& Y Tencer. 1968. Soybean saponins. Fate of ingested soybean saponins and the physiological aspect of their hemolytic activity. Journal of Agricultural and Food Chemistry 16: 1031-1035.

Haug T, AK Kjuul, OB Styrvold, E Sandsdalen, ØM Olsen \& K Stensvåg. 2002. Antibacterial activity in Strongylocentrotus droebachiensis (Echinoidea), Cucumaria frondosa (Holothuroidea), and Asterias rubens (Asteroidea). Journal of Invertebrate Pathology 81: 94-102.
Ismail H, S Lemriss, Z Ben-Aoun, L Mhadhebi, A Dellai, Y Kacem, P Boiron \& A Bouraoui. 2008. Antifungal activity of aqueous and methanolic extracts from the Mediterranean sea cucumber, Holothuria polii. Journal of Medical Mycology 18: 23-26.

Jha RK \& X Zi-rong. 2004. Biomedical compounds from marine organisms. Marine Drugs 2: 123-146

Kalinin VI, NG Prokofieva, GN Likhatskaya, EB Schentsova, IG Agafonova, SA Avilov, \& OA Drozdova. 1996. Hemolytic activities of triterpene glycosides from the holothurian Order Dendrochirotida: Some trends in the evolution of this group of toxins. Toxicon 34: 475-483.

Kalinin VI, AS Silchenko, AS Avilov, VA Stonik \& AV Smirnov. 2005. Sea cucumbers triterpene glycosides, the recent progress in structural elucidation and chemotaxonomy. Phytochemistry Reviews 4: 221-236.

Kelly MS. 2005. Echinoderms: Their culture and bioactive compounds. Progress in Molecular and Subcellular Biology 39: 139-165.

Kobayashi M, M Hori, K Kan, T Yasuzawa, M Matsusi, Sh Suzuki \& I Kitagawa. 1991. Marine natural products. XXVII. Distribution of lanostane-type triterpene oligo glycosides in ten kinds of okinawan sea cucumbers. Chemical and Pharmaceutical Bulletin 39: 2282-2287.

Kuroda M, Y Mimaki, F Hasegawa, A Yokosuka, Y Sashida \& H Sakagami. 2001. Steroidal glycosides from the bulbs of Camassia leichtlinii and their cytotoxic activities. Chemical and Pharmaceutical Bulletin 49: 726-731.

Larrain A. 1995. Biodiversidad de equinodermos chilenos: estado actual del conocimiento y sinopsis biosistematica. Gayana Zoología 59: 73-96.

Levina EV, AI Kalinovsky, PS Dmitrenok, EA Martyyas \& VA Stonik. 2010. Two new steroidal saponins, hylodoside A and novaeguinoside Y, from the starfish Leptasterias hylodes reticulata and Culcita novaeguineae (juvenile). Natural Products Communications 5: 1737-1742.

Li R, Y Zhou, Z Wu \& L Ding. 2006. ESI-QqTOFMS / MS and APCI-IT-MS/MS analysis of steroid saponins from the rhizomes of Dioscorea panthaica. Journal of Mass Spectrometry 41: 1-22.

Ma X, K Namita, PD Collin, O Goloubeva \& AM Fulton. 2012. Frondoside A inhibits breast cancer metastasis and antagonizes prostaglandin E receptors EP4 and EP2. Breast Cancer Research and Treatment 132: 1004-1008.

Maier MS, AJ Roccatagliata, A Kurriss, H Chludil, AM Seldes, CA Pujiol \& EB Damonte. 2001. Two new cytotoxic and virucidal trisulfated glycosides from the Antarctic sea cucumber Staurocucumis liouvillei. Journal of Natural Products 64: 732-736. 
Makarieva TN, VA Stonik, II Kapustina, VM Boguslavsky, AS Dmitrenoik, VI Kalinin, ML Cordeiro \& C Djerassi. 1993. Biosynthetic studies of marine lipids. 42. Biosynthesis of steroid and triterpenoid metabolites in the sea cucumber Eupentacta fraudatrix. Steroids 58: 508-517.

Mamelona J, E Pelletier, KG Lalancette, J Legault, S Karboune \& S Kermasha. 2007. Quantification of phenolic contents and antioxidant capacity of Atlantic sea cucumber, Cucumaria frondosa. Food Chemistry 104: 1040-1047.

Manger R, L Leja, S Lee, J Hungerford \& M Wekell. 1993. Tetrazolium-based cell bioassay for neurotoxins active on voltage-sensitive sodium channels: semiautomated assay for saxitoxins, brevetoxins, and ciguatoxins. Analytical Biochemistry 214: 190-194.

Mayer AMS \& KR Gustafson. 2004. Marine pharmacology in 2001-2: antitumour and cytotoxic compounds. European Journal of Cancer 40: 2676-2704.

Mayer AM \& KR Gustafson. 2008. Marine pharmacology in 2005-6: antitumour and cytotoxic compounds. European Journal of Cancer 44: 2357-2387.

Mimaki Y, A Yokosuka, M Kuroda \& Y Sashida. 2001. Cytotoxic activities and structure-cytotoxic relationships of steroidal saponins. Biological and Pharmaceutical Bulletin 24: 1286-1289.

Mujoo K, V Haridas, JJ Hoffmann, GA Wachter, LK Hutter, Y Lu, ME Blake, GS Jayatilake, D Bailey, GB Mills \& JU Gutterman. 2001. Triterpenoid saponins from Acacia victoriae (Bentham) decrease tumor cell proliferation and induce apoptosis. Cancer Research 61: 5486-5490.

Munro MHG, JW Blunt, EJ Dumdei, SJH Hickford, RE Lill, SX Li, CN Battershill \& AR Duckworth. 1999. The discovery and development of marine compounds with pharmaceutical potential. Journal of Biotechnology 70: $15-25$.

Neira C, M Hoeneisen, M Silva \& L Minale. 1985. Marine organic chemistry, IV. Structure of the principal aglycones from the starfish Meyenaster gelatinosus. Journal of Natural Products 48: 848-848.

Pasqualotto AC \& DW Denning. 2008. New and emerging tratments for fungal infections. Journal of Antimicrobial Chemotherapy 61: i19-i30.

Pettit GR, F Gao, PM Blumberg, CL Herald, JC Coll, Y Kamano, NE Lewin, JM Schmidt \& JC Chapuis. 1996. Antineoplastic Agents. 340. Isolation and structural elucidation of bryostatins 16-18. Journal of Natural Products 59: 286-289.

Pettit GR, CL Herald, DL Doubek, DL Herald, E Arnold \& J Clardy. 2002. Isolation and structure of bryostatin. Journal of the American Chemical Society 104: 6846-6848.
Regalado EL, D Tasdemir, M Kaiser, N Cachet, P Amade \& OP Thomas. 2010. Antiprotozoal steroidal saponins from the marine sponge Pandaros acanthifolium. Journal of Natural Products 73: 1404-1410.

Rinehart KL, JB Gloer Jr, RG Hughes Jr, HE Renis, JP McGovren, EB Swynenberg, DA Stringfellow, SL Kuentzel \& LH Li. 1981. Didemnins: antiviral and antitumor depsipeptides from a Caribbean tunicate. Science 212: 933-935

Rodriguez J, R Castro \& R Riguera. 1991. Holothurinosides: new antitumour non sulphated triterpenoid glycosides from the sea cucumber Holothuria forskali. Tetrahedron 47: 47534762.

Ruggieri G. 1976. Drugs from the sea. Science 194: 491-497.

Scheuer P. 1990. Some marine ecological phenomena: chemical basis and biomedical potential. Science 248: 173-177.

Selvin J \& AP Lipton. 2004. Antifouling activity of bioactive substances extracted from Holothuria scabra. Hydrobiologia 513: 251-253.

SERNAPESCA. 2010. Anuario estadístico de pesca. Servicio Nacional de Pesca, Valparaíso. <http://www.sernapesca.cl>

Silchenko AS, VA Stonik, SA Avilov, VI Kalinin, AI Kalinovsky, AM Zaharenko, AV Smirnov, E Mollo \& G Cimino. 2005. Holothurins B2, B3 and B4, new triterpene glycosides from Mediteranean sea cucumbers of the genus Holothuria. Journal of Natural Products 68: 564-567.

Silchenko AS, SA Avilov, AI Kalinovsky, PS Dmitrenok, VI Kalinin, J Morre, ML Deinze, C Woodward \& PD Collin. 2007. Glycosides from the North Atlantic sea cucumber Cucumaria frondosa $\mathrm{V}$ : structures of five new minor trisulfated triterpene oligoglycosides, frondosides A7-1, A73, A7-4, and isofrondoside C. Canadian Journal of Chemistry 85: 626-636.

Silchenko AS, SA Avilov, VI Kalinin, AI Kalinovsky, PS Dmitrenok, SN Fedorov, VG Stepanov, Z Dong \& VA Stonik. 2008. Constituents of the sea cucumber Cucumaria okhotensis. Structures of okhotosides B1-B3 and cytotoxic activities of some glycosides from this species. Journal of Natural Products 71: 351-356.

Stonik VA, VI Kalinin \& SAAvilov. 1999. Toxins from the sea cucumbers (Holothuroids): chemical structures, properties, taxonomic distribution, biosynthesis and evolution. Journal of Natural Toxins 8: 235-248.

Sugawara T, N Zaima, A Yamamoto, S Sakai, R Noguchi \& T Hirata. 2006. Isolation of sphingoid bases of sea cucumber cerebrosides and their cytotoxicity against human colon cancer cells. Bioscience, Biotechnology and Biochemistry 70: 2906-2912. 
Van Dyck S, P Gerbaux \& P Flammang. 2009. Elucidation of molecular diversity and body distribution of saponins in the sea cucumber Holothuria forskali (Echinodermata) by mass spectrometry. Comparative Biochemistry and Physiology Part B: Biochemistry and Molecular Biology 152: 124-134.

Yang P, P Collin, T Madden, D Chan, B Sweeney-Gotsch, D McConkey \& RA Newman. 2003. Inhibition of proliferation of PC3 Cells by the branched-chain fatty acid,12-methyltetradecanoic acid, is associated with inhibition of 5-lipoxygenase. The Prostate 55: 281-291.
Zahavi T, L Cohen, W Batia, L Schena, A Daus, T Kaplunov, J Zutkin, R Ben-Arie \& S Droby. 2000. Biological control of Botrytis, Aspergillus and Rhizopus rots on table and wine grapes in Israel. Postharvest Biology and Technology 20: 115-124.

Zou Z, Y Yi, H Wu, X Yao, L Du, W Jiuhong, CC Liaw \& KH Lee. 2006. Intercedensides D-I, cytotoxic triterpene glycosides from the sea cucumber Mensamaria intercedens Lampert. Journal of Natural Products 69: 1530-1530.

Received 28 May 2012 and accepted 17 December 2012

Editor: Claudia Bustos D. 